\title{
VULNERABILITY OF WASTEWATER TREATMENT PLANTS AND WASTEWATER PUMPING STATIONS TO EARTHQUAKES
}

\author{
Mohammad Reza ZARE ${ }^{1}$, Suzanne WILKINSON ${ }^{2}$ and Regan POTANGAROA ${ }^{3}$ \\ ${ }^{1}$ Department of Civil and Environmental Engineering, Faculty of Engineering, University of \\ Auckland, Auckland, New Zealand \\ E-mail address: mzar004@aucklanduni.ac.nz \\ 2 Department of Civil and Environmental Engineering, Faculty of Engineering, University of \\ Auckland, Auckland, New Zealand \\ E-mail address: s.wilkinson@auckland.ac.nz \\ ${ }^{3}$ School of Architecture, Unitec, Auckland, New Zealand \\ E-mail address: rpotangaroa@unitec.ac.nz
}

Received 21 July 2010; accepted 1 November 2010

\begin{abstract}
Earthquakes are the most common natural hazard in New Zealand which can affect lifelines in populated areas. This research takes into account earthquake effects on treatment plants and pumping stations in wastewater systems as a lifeline. Wastewater treatment plants in four earthquake prone areas in New Zealand were selected for the purpose of assessing their vulnerabilities to earthquakes. Results showed that simple upgraded wastewater treatment plants are the most vulnerable type of wastewater treatment plants in New Zealand. Earthquake vulnerability of 45 wastewater pumping stations in 3 earthquake prone cities in New Zealand was also assessed. The assessment proved that non-structural components are among the most vulnerable parts in wastewater pumping stations. Since structural vulnerability of some wastewater pumping stations is notable, it requires a need for an immediate rehabilitation plan.
\end{abstract}

KEYWORDS: Earthquakes; Vulnerability; Wastewater treatment plant; Wastewater pumping station

\section{INTRODUCTION}

The wastewater system (WWS) is one of few public facilities which has direct impact on communities, especially in concentrated urban areas. The malfunction of such a facility rapidly affects a large number of people. Wastewater systems in densely populated areas have been designated as lifelines which deserve particular attention due to their direct impact on community health.Wastewater system failure not only endangers human health, but it can also pollute the environment. Furthermore, earthquakes not only damage wastewater systems, but also cause water pollution and environmental issues due to the direct discharge of wastewater in rivers or seas (EERI, 2010; Tang et al., 2010).

Vulnerability in wastewater systems can be categorized on the vulnerability of each part of the system, including wastewater treatment plants (WWTP), wastewater pumping stations (WWPSs) and pipelines. The vulnerability of each WWS component reflects its susceptibility 
to failure due to damages incurred by an earthquake. For instance, if any particular WWPS cannot pump received wastewater to the designated outlet due to earthquake caused damage then the WWP will be vulnerable to an earthquake. The vulnerability in WWTPs can be defined as the factors which affect the failure in the treatment process or the decreasing outlet quality of treated wastewater which get released to the environment.

The effects of earthquakes on wastewater systems both directly and indirectly influence human health and environment simultaneously. Direct effects of earthquakes on wastewater systems are the damages which are caused directly due to ground shaking or permanent ground movement (Heubach, 2002). For instance, direct damages to treatment plants or wastewater pumping stations can be both structural and non-structural failures on different parts of the system (Heubach, 2002). Indirect damage from an earthquake on wastewater systems can be caused by a tsunami, flood (Edwards, 2005) or even a change of oceanographic characteristics near the wastewater treatment plant outlet (Morkoc et al., 2007). The earthquake vulnerability assessment of New Zealand's wastewater treatment plants and wastewater pumping stations has been made as well as suggestions for decrease earthquake vulnerability to New Zealand's wastewater systems.

\section{EARTHQUAKE EFFECTS ON WASTEWATER SYSTEMS}

Earthquake effects on recently upgraded treatment plants during two main earthquakes in US and Taiwan have shown how the loss of power significantly affects wastewater systems, particularly pumping stations (Lund et al., 1998; Schiff and Tang, 2000). However, treatment plants that had been upgraded and constructed with new building codes withstood the earthquakes well with only minor damages.
The San Jose wastewater treatment facilities and the Watsonville primary wastewater treatment plant were examples of two earthquake resistant plants in the 1989 Loma Prieta earthquake (Lund et al., 1998). No structural damage was reported for the Alvarado wastewater treatment plant, South Bay Side, Scott Valley wastewater treatment plants and Santa Cruz regional wastewater treatment plant (Lund et al., 1998). Most of the wastewater treatment plants in the earthquake impacted areas during the 1989 earthquake had been upgraded with new buildings and structural codes before the earthquake (Lund et al., 1998).

According to the 1995 NCEER report, the Higashinda wastewater treatment plant, the greatest wastewater treatment plant in the 1995 Kobe earthquake affected area, was severely damaged (NCEER, 1995). Lateral ground deformation and differential settlement caused severe damage in the plant. The earthquake affected facilities located in the plant such as building equipment, pipes and all other relevant facilities. The earthquake also affected most of the wastewater pumping station, damaging 20 of the 23 pumping stations. The most significant damage to the pumping station was power outage, however after power restoration, most of the WW pumping stations started working despite reports of building structure damage and caisson damage (NCEER, 1995).

The wastewater treatment plants and wastewater pumping stations suffered minor damages by the 1999 Taiwan earthquake, however power outage proved to be the most significant effect on industrial treatment plants and WWPSs (Schiff and Tang, 2000). The 1995 Northridge earthquake did not cause significant and notable damage in WWTPs, however commercial power outage affected 54 WWPSs in the affected areas (Moehle, 1995; Schiff, 1995).

The 1999 Turkey earthquake caused severe damages to the local water and wastewater 
system especially in the areas affected by ground settlement (Bendimerad et al., 2000). However after the earthquake, the Izmit wastewater treatment plant was closed due to the heavy damage of mechanical equipment (Erdik, 1999). Wastewater systems suffered intensive damage in the 2010 Chile earthquake. Earthquake damage was extended into wastewater treatment plants, large diameter interceptor pipes and small diameter connection pipes (EERI, 2010; Tang et al., 2010).

During the 1987 Edgecombe earthquake in NZ, wastewater pumping stations with submersible pumps did not suffer damage and the wastewater treatment plants in Whakatani and Edgecumbe stood well (Butcher et al., 1998). The 2007 Gisborne earthquake caused minor damage to mechanical parts in some wastewater pumping stations (Rentoul, 2008). The wastewater treatment plant and wastewater pumping stations continued working without major damages in the Ormond earthquake of 1993 (Read and Sritharan, 1993).

Edward (2005) revealed that indirect damage of earthquakes can even be flood damages created by tsunami waves. For instance, during the 2004 tsunami in Thailand, treatment plants and pumping stations flooded which caused the whole wastewater system to fail (Edwards, 2005). Another example of indirect impact of earthquake on wastewater systems is the change of oceanographic characteristics near wastewater treatment plant outlets. The ocean pollution in Izmit bay was an instance of such indirect impact after the 1999 Turkey earthquake (Morkoc et al., 2007). In the 1931 Napier earthquake of New Zealand, the inner harbour floor uplifted and the tidal current force decreased. Inadequate tidal current had caused the accumulation of sewage solids near the harbour entrance. Furthermore, the consumption of contaminated shellfish caused some outbreak of typhoid after the earthquake (Napier City Council, 2008).
The above case studies show that earthquakes usually caused minor damages to wastewater treatment plants and wastewater pumping stations despite the severe earthquake effects on wastewater treatment plants in the 1995 Japan and the 2010 Chile earthquakes. The liquefaction and permanent ground deformation were the two main causes of severe damage as a result from such earthquakes. The main problem reported for treatment plants and pumping stations was power outage. In order to demonstrate the vulnerability of wastewater treatment plants and pumping stations to earthquakes in New Zealand, four wastewater treatment plants including 45 wastewater pumping stations were taken into account.

\section{NEW ZEALAND TREATMENT PLANTS AND EARTHQUAKE VULNERABILITY}

Each city in New Zealand with a population greater than 30000 has at least one wastewater treatment plant. Wastewater treatment plants (WWTP) in New Zealand vary from simple treatment plants (Gisborne WWTP) to the most complicated treatment plants (Wellington and Auckland WWTP). In this study the WWTPs were classified into three main groups: advanced technology wastewater treatment plants (Wellington and Hutt City), simple milli-screening WWTP (Gisborne) and simple milli-screening with ponds WWTP (Blenheim).

The Wellington WWTP was built in 1998 while the Hutt City WWTP was commissioned in 2001 (Capacity-Co., 2004). Blenheim treatment plant upgrading is under construction, whereas construction of Gisborne's treatment plant will be started in the near future (Gisborne District Council, 2009). The first Hutt City treatment plant was established in 1982 , was upgraded and restarted operation in 2001. Although the initial treatment plant in Hutt 
City comprised of a screening unit, the postupgrade was classified as an advance WWTP with several treatment processes (CapacityCo., 2004).

Some regional wastewater systems still rely on simple treatment systems that only filter collected wastewater and release it to nature. Gisborne's wastewater milli filtering station is an example of a simple WWTP that only filters collected wastewater and releases it to the harbour, although the design of a new treatment plant is in progress. The Napier wastewater treatment plant is another example of simple wastewater treatment plant (WWTP) which entails milli-screening of the collected wastewater and pumping to Hawke's Bay via a 1600 metre of outfall marine pipeline (Napier City Council, 2008). The Blenheim WWTP is another example of simple WWTP which effluent after milli-screening is transferred to ponds for further treatment.

Wastewater treatment plants located in main cities in New Zealand usually include similar components. Common features in NZ's WWTPs include pumping stations, sedimentation tanks, reactors, clarifiers, micro-filtration units, ultra violet disinfection parts, storage buildings, labs, administration buildings, discharge pipelines and outlet points. Simple WWTPs are located in small cities and usually comprise of simple filtration units and pumping stations. Different sources of wastewater in various cities lead to a variety of treatment processes, although treatment plants in NZ normally have different capacities and layouts with common main components. WWTPs in the earthquake prone areas are expected to withstand particular earthquakes hence each part of it should resist earthquake forces. Each WWTP is a combination of various types of building and apparatus which should be able to operate simultaneously. If the administrative buildings and their facilities suffer an earthquake and are not to be used, the whole system will be affected. For instance, water system recovery was delayed in the 1985 Mexico City, 1991 Philippines, 1995 Kobe and 2001 Nisqually earthquakes because of administrative building damages caused by the earthquakes (Heubach, 2002). Each part of the treatment plant has a particular vulnerability to an earthquake which can be affected differently (Heubach, 2002). For instance, Seiche should be considered in sedimentation tanks and clarifiers in which all mechanical equipment housed in them be designed to tolerate the wave effect caused by earthquakes (Heubach, 2002). Clarifier structures are usually resistant to ground shaking or ground movement. However, sloshing can damage them, for instance sloshing damaged clarifiers in the 1989 Loma Prieta Earthquake (Heubach, 2002). Structural design codes for WWTP should conform with nationally recognized codes (Vesilind, 2003). Local earthquake codes should be up to date with new design criteria while earthquake codes should cover all buildings and structures.

WWTP vulnerability in NZ can be divided into the vulnerability of recently upgraded or constructed modern treatment plants located in populated regions and the vulnerability of simple treatment plants in small cities. Power outage after an earthquake is the most notable susceptibility in both types of wastewater treatment plants. All visited wastewater treatment plants have a power generator in the case of an emergency outage, although in large scale earthquakes which power transmission lines can be suffered significantly, emergency generators would not be able to produce sufficient power to run all systems during the power recovery period. High demand for electricity in different sections of WWTPs, particularly in UV disinfection units make WWTPs in populated regions more vulnerable to a power outage, in contrast with other smaller wastewater treatment plants. Power outage is the most significant vulnerability in WWTP's of NZ's large cities. Due to such power outages, 
enormous amounts of untreated or partially treated wastewater can be discharged to the environment. Therefore environmental pollution is the most probable consequence of continuous power shortage in WWTPs in New Zealand (Bannatyne, 2004).

This study shows that major WWTPs in New Zealand were built or upgraded recently and are complied with the updated earthquake building codes. The advanced treatment plants in New Zealand such as Wellington, Hutt City and Auckland WWTPs were built after 1998 which means construction of the WWTPS were complied with the recently established building codes. The past notable earthquake after 1978 showed that buildings constructed under the NZS 3904 stood well after the earthquakes, although after 1978, the building codes were upgraded several times and amended before the design date of wastewater treatment plants (Beattie and Thurston, 2006). Considering the 1992 building code in NZ, where building behaviour in earthquakes was taken into account, and by considering the construction and design dates of WWTPs in New Zealand, advanced WWTPs in NZ are not vulnerable to earthquakes. As a result, WWTPs appear to be the least vulnerable component of wastewater systems in New Zealand.

Earthquake vulnerability of simple WWTPs in New Zealand is equal to that of wastewater pumping stations. Screening units in simple WWTP's were installed during the last two decades where new building codes and earthquake forces were taken into account in their design. The main issue in simple treatment plants in New Zealand, such as the ones in Gisborne and Blenheim, is the vulnerability of their wastewater pumping stations.

\section{WASTEWATER PUMPING STATIONS VULNERABILITY TO EARTHQUAKES}

Wastewater systems are designed to transmit wastewater by gravitational force, the most reliable and economical way of conveying fluids. Economical issues and technical difficulties are the main obstacles to using gravitational force. Burying pipe to gravity flow cost more than to construct a wastewater pumping stations in terms of technical difficulties and environmental effects, especially in some soft soils. Due to such barriers, pumping stations are one of the main parts of each wastewater system, particularly in the wastewater reticulation systems (Read, 2004). Pumping stations are also one of the main parts in the treatment plant and treated wastewater discharge stations. The main function of pumping stations in sewage reticulation is to transmit sewage to the upper levels by means of gravity. In some cases, wastewater or treated wastewater is completely carried under pressure, powered by one or several pumping stations. The $18 \mathrm{~km}$ pressure pipe in the Hutt City wastewater system is a good instance of the pressure system, which carries treated wastewater to the discharge point in Wellington harbour (CapacityCo., 2008).

\section{WASTEWATER PUMPING STATIONS IN NEW ZEALAND}

Various pumping stations were selected across three earthquake-prone cities in New Zealand to investigate WWPSs vulnerability to earthquakes. Gisborne and Hutt City in the North Island and Blenheim in the South Island were the three earthquake-prone regions chosen to investigate their WWPSs earthquake vulnerability. Since each case study was located across different geological region with varying soil types influenced by different active faults, each case should experience different earthquake magnitudes.

Hutt city is located inside the southern part of the North Island and northeast of New Zealand's capital. Hutt City can be affected by several active faults, Wellington fault being the most significant one which passes from 
the southwest to northeast of the city. Hutt City is laid on variable Quaternary-age sediments comprising from soft and loose sediment to compact coarser-grained materials. Nearsurface soft sediments with thickness greater than $10 \mathrm{~m}$ are the predominant soil type in Hutt City. The Wellington fault has a significant effect on the seismic vulnerability of Hutt City. MMI caused by the fault varies from IX to XI whereas peak ground acceleration varies from 0.5 to $0.8 \mathrm{~g}$ (Van Dissen et at., 1992).

Blenheim is located in the Marlborough region, northeast of the South Island. It has a high level of seismic vulnerability due to the close proximity to the Wairau and Awatere faults. Blenheim's seismic vulnerability can also be affected by the Marlborough fault system. Its surrounding faults can cause earthquakes with magnitudes from 6.9 to $7.9 \mathrm{M}_{\mathrm{w}}$. The city can experience an earthquake every 28-51 years although the average time between earthquakes due to the two main faults is 350 to 950 years. An earthquake magnitude of 7.5 creates earthquake intensities of VII to more than IX and ground acceleration of $1.4 \mathrm{~g}$ (Robertson and Smith, 2004). Blenheim is located on the Wairau Plain where its soil types are a combination of the Wairau River sediments combined with coastal and lagoon deposits, fluvial, swamp deposits and glacial outwash gravel.

Gisborne is located on the main seismic region where it can be affected by the subducttion of the Pacific Plate and Australian Plate. Three active faults in the northwest of Gisborne can also affect its seismic vulnerability (Read and Sritharan, 1993). The 1993 and 2007 earthquakes of Gisborne were the direct cause of the subduction of the Pacific Plate (FrançoisHolden et al., 2008). Gisborne is located on young, soft and consolidated sediments (Bevin, 2000). The city is laid on Holocene sediment which is created by flooding and sea level fluctuating. People living in Gisborne should expect 13 earthquakes with magnitudes greater than 4 within $100 \mathrm{~km}$ of Gisborne annually (Webb et al., 1985). Gisborne can experience earthquakes with magnitudes greater than MMI=VIII every 200 years and earthquakes greater than MMI=IX every 1000 years.

19, 13 and 20 WWPSs in Blenheim, Gisborne and Hutt City were selected respectively to show how vulnerable WWPSs are. WWPSs' vulnerability to earthquakes in each city was classified and investigated. The following observations are the result of site visiting, technical interviewing and data analysing done by the authors in 2008 and 2009.

New Zealand's wastewater pumping stations are classified into two main groups: drywell WWPTs and wet-well WWPSs. Pumps in dry well WWPTs are located in separate underground structures whereas in wet-well WWPSs submersible pumps are installed inside the reservoir. Usually, wastewater pumping stations which were built before 1966 are drywell pumping stations. For instance, all 8 wastewater pumping stations built before 1966 in Gisborne are dry-well WWPSs (Gisborne District Council, 2008). WWPSs earthquake vulnerability was divided into two main groups: structural vulnerability and non structural vulnerability. To evaluate WWPSs structural vulnerability, WWPSs were split into two main sets: WWPSs with above ground building and WWPSs without above ground building.

This research showed buildings of WWPSs mounted on top of under-ground structures (usually in dry-well WWPSs) house all electronic equipment including control boards, telecommunication and data transferring devices. The WWPS building is also the access point to the dry well for maintenance. During the development of the cities, remote controlling and telecommunication devices were installed in WWPSs and mounted on the building walls. All relevant data requires WWPSs monitoring, including the wastewater level, working hours of each pump, the discharge rate and the security signals which continuously get 
recorded and transferred to the control room. SCADA, according to collected data, controls the whole wastewater system. Failure of any installed instrument inside the building makes the WWPS useless whereas the failure of each WWPS directly affects the whole wastewater reticulation system. Furthermore, the WWPS's building is the access point to the underground structure which includes pumps, valves and piping. The building collapse not only affects whole systems function but also hinders repair processes of affected WWPSs. Building vulnerability in the wastewater pumping stations was taken into account as a main susceptible factor.

Various parameters were taken into consideration to demonstrate earthquake vulnerability of WWPSs' building. For the assessment of WWPSs vulnerability, building characteristics, (such as age, type) including geological and geotechnical characteristics (such as soil type, liquefaction susceptibility), were applied to reveal the WWPSs' building vulnerability to earthquakes (see Building Act, 2004; Standards New Zealand, 2004; NZSEE, 2006). The latest earthquake vulnerability assessment of buildings in NZ has been applied to accurate initial assessments (NZSEE, 2006). Building age is one of the main factors which increase building vulnerability in face of earthquakes (NZSEE, 2006).

Various building codes have been developed in New Zealand to satisfy required standards during urban area development. The first building code was established in 1935 and renewed several times to decrease its deficiencies (Beattie and Thurston, 2006). In order to add building material and design criteria to the first building code in 1935, several building codes have been amended. For instance, the building codes of 1965, 1976, 1984 and 1992 added more details to the first NZ building code of 1935 . Rather than recommending specific material, design and construction, the 1992 building code outlined the performance of buildings during an earthquake. The building code showed how buildings should react to withstand earthquake loads. The 1992 building code has since been amended nine times till 2004. Beattie and Thurston (2006) showed that the first earthquake building code with sound engineering approach was established in 1976. Buildings built prior to 1976 may have had more vulnerability to earthquakes compared to buildings built between 1976 and 1992. Although the building were design and constructed according to the 1992 building codes seem to withstand earthquakes very well.

Regarding the collected data from each city council, Figure 1 illustrates WWPSs age among three earthquake-prone cities (Hutt City, Gisborne and Blenheim). As Figure 1 shows the oldest WWPSs belong to the Blenheim wastewater system although, the percentage of new WWPSs also belong to Blenheim. This shows the development of Blenheim city and the replacement of aged WWPS's. About $60 \%$ of Hutt City and Blenheim's wastewater pumping stations were built or refurbished before 1976, followed by $40 \%$ of Gisborne's WWPSs. Finally, it should be summarized that in three selected cities in New Zealand, more than $40 \%$ of all wastewater pumping stations were built before 1976 , which means at least $40 \%$ of wastewater pumping stations buildings should be accurately evaluated for earthquake vulnerability. The construction dates in Figure 1 represent refurbishment date of each pumping stations instead of initial construction dates.

As observed during this research, another factor which affects earthquake vulnerability of a building is its material type. For instance, masonry buildings are the most common building types in WWPSs, although some concrete buildings are also available in NZ's WWPSs. Roofs in the WWPSs' buildings are usually concrete slab, wood frame with ceramic tiles or steel frames with steel sheets on top. The WWPSs' building height varies between 2 and 2.50 meters except with main WWPSs. 


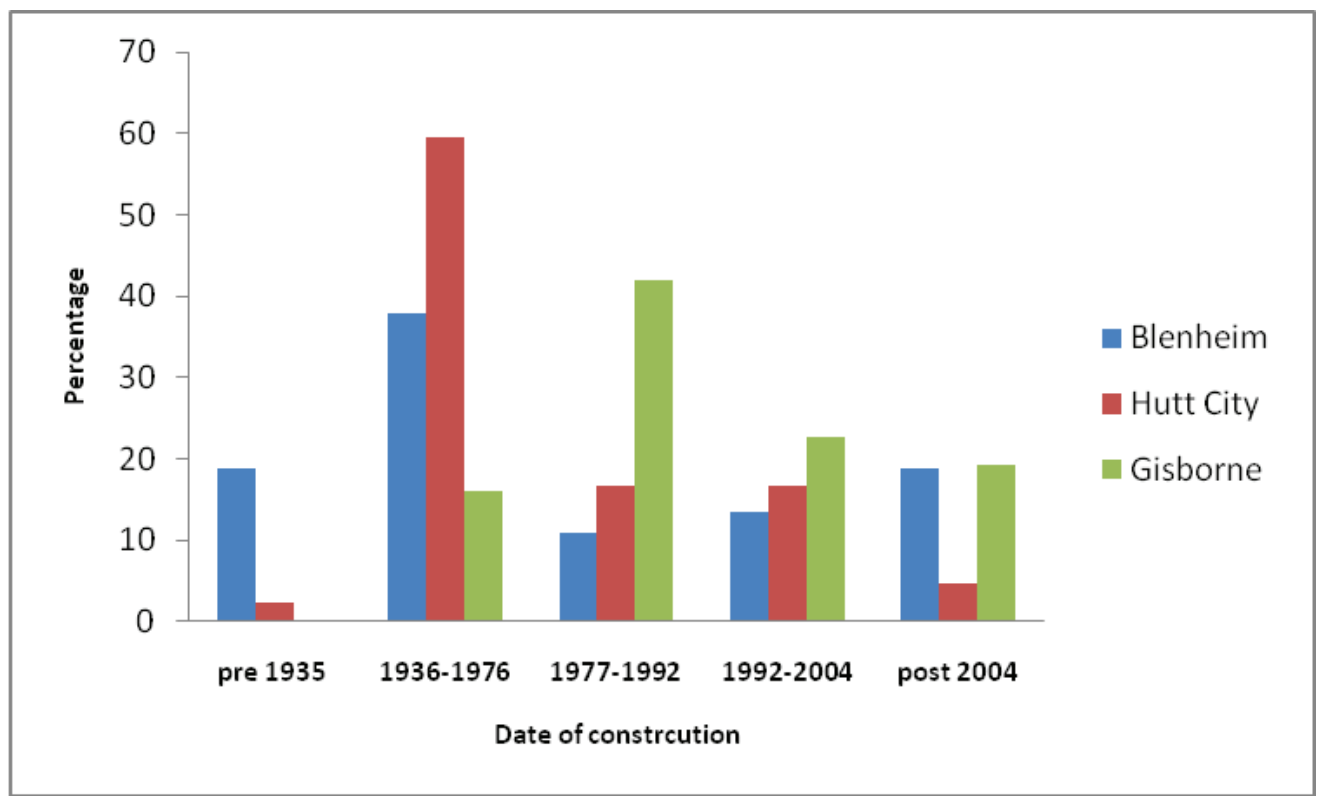

Figure 1. Date of construction in three cities' wastewater pumping stations

Another factor which affects vulnerability of wastewater pumping station buildings is the irregularity in building plans. Most WWPSs' buildings in this study have almost regular plans (rectangular plan) but with different plan types. For Instance, Gisborne's WWPSs have different types of plans compared with Blenheim and Hutt City's WWPSs. As observed, circular and hexagonal plans are common in Gisborne's wastewater reticulation. WWPS buildings, not including some trunk WWPSs in Hutt City and main WWPSs in two other cities, have small area sizes while building area in common WWPSs vary between 6 to 25 square meters. WWPSs in Gisborne and Hutt City have greater building area compared with Blenheim's WWPSs. Recent field studies showed that superficial physical condition of all assessed WWPSs were fine with no sign of deterioration or crack on above ground structures was visually detected. However, concrete deterioration in wet well structures has been seen in some WWPSs. Detailed tests and analysis should be done to accurately show the vulnerability of building structures.

Wastewater pumping stations' wells in New Zealand are usually made by precast concrete or cast in place concrete. However in some cases, the reservoir wells have been made of fibreglass tank. Early wastewater pumping stations on the other hand were made by place concrete. Concrete well deterioration was not obvious in the majority of cases at least above the reservoir water level. Further structural evaluation accompanied with some material tests are required to accurately evaluate underground ground structure vulnerability to ground shaking.

\section{INITIAL ASSESSMENT OF HUTT CITY WWPS}

Regarding the greatest numbers of WWPSs with buildings in the Hutt City wastewater system compared with Gisborne and Blenheim, initial earthquake assessment procedure 
recommended by NZSEE (2006) was applied to disclose the Hutt City WWPSs' building vulnerability to earthquakes. The initial construction dates of Hutt City WWPSs in the city wastewater reticulation were applied in the initial assessment procedure because refurbishment was only done for mechanical, electrical and telecommunication devices. Assessment made of Hutt City WWPSs without trunk pumping stations showed, $41 \%, 31.8 \%, 22.7 \%$ and $4.5 \%$ of the WWPSs were built before 1935, between 1936 and 1976, between 1977 and 1992, and after 1992 respectively.

The vulnerability assessment methodology based on NZSEE (2006) comprises of 7 steps to fully grade building vulnerability to earthquakes. The first step provides general information for each pumping station to show building features. In the second step, baseline percent and new building standard is determined by calculating and considering near fault and hazard factors, building importance level, return period scaling factor and ductility scaling factor. Performance achievement ratio and the percentage of new building standard are determined in step 3 and 4 respectively. Step 5 shows if the studies building is an earthquake prone building while step 6 reveals earthquake risk. Finally, the last step provides provisional grading for seismic risk of building.

NZSEE (2006) recommends that if the calculated percentage of the New Building Standard (\%NBS) for each particular building be less than two thirds of the NBS, then the building is vulnerable to earthquakes and should be retrofitted. Although the NZ Building Act (2004) declares if calculated \%NBS be less than one third of the new building standard then the building is an earthquake prone building.

The NZSEE initial assessment requires earthquake and geological characteristics of the place where pumping station are mounted on. Geological characteristics of each WWPS in Hutt City including soil types were extracted from the available sources (Dellow, 1992;
Van Dissen et al., 1992). Hutt City WWPSs GIS data base was applied to find location and age of each WWPS in the Hutt City wastewater system. Liquefaction vulnerability map of Hutt City was applied to modify calculated $\%$ NBS for the initial assessment (MWH, 2005). Earthquake characteristics of city derived from structural design action 2004 (Standards New Zealand, 2004).

WWPSs structure assessment by the author revealed that $57 \%$ of the Hutt City WWPSs which were built before 1957 are significantly vulnerable to earthquake and should be retrofitted according to the 2004 building act. Regarding the NZSEE (2006) recommendation for the retrofitting of buildings, $81 \%$ of the pumping stations should be renovated with new building codes. The assessment showed that $19 \%$ of existing pumping stations have buildings which are able to withstand moderate earthquake shaking. Since WWPSs, as required buildings, may be of great concern for any specific region, the NZSEE 2006 recommendation seems more reliable and appropriate.

\section{NON STRUCTURAL VULNERABILITY OF WWPS}

Non structural vulnerabilities in the NZ's WWPSs were categorized by the authors into two main types, including vulnerability of electrical and electronic equipment, and mechanical component vulnerability. Regional and common WWPSs transmit collected wastewater from each region to main collectors or trunks pipeline. These pumping stations usually house two pumps, two check valves, two control valves, flow-meter, pipes and fitting, control panels, data transmitting and telecommunication instruments. Alongside the mechanical and electrical instruments, each pumping station consists of a reservoir to collect and pump wastewater to the designated point. Under-ground structures in pumping 
stations usually consist of two wells: dry and wet wells, or one wet well. Wastewater discharges to the wet well and pumps to the designated point. Dry well in dry-well WWPSs houses fixed pumps, valves, pipes, fitting and access point. In new pumping stations which are usually wet-well WWPSs, there is no dry well. Consequently, pumps and piping directly are installed in the wet well. Fixed pumps in dry-well WWPSs are replaced by submersible pumps in wet-well WWPSs which are directly installed.

Vulnerability of the electrical and electronic equipment in WWPSs should be taken into account such as the monitoring and controlling devices which control the system. This type of vulnerability was divided into two main groups of WWPSs: WWPSs with a building and WWPSs without a building. Wet-well WWPSs which electrical and electronic equipment is installed in the control panel outside WWPSs' buildings are much less vulnerable to earthquakes compared with dry-well WWPSs. Wet-well WWPSs house all electrical and electronic equipment in a steel box mounted on the concrete pad near the underground structure, whereas electrical and electronics panels in dry-well WWPSs are simply mounted on the building walls without adequate fixing supporters. WWPSs with building cover around half of the WWPSs in all three cities where inadequate fixing of electrical and electronic equipment is common to all of them. Even if building walls are able to stand earthquake shaking, the toppling and falling of inadequately mounted equipment can cause a significant failure in WWPSs during a strong earthquake.

Mechanical equipment, including pumps, piping and fitting are the main parts in each WWPS where their vulnerability can instantly affect the whole system function. Earthquake vulnerability in mechanical parts is divided into the pumps' vulnerability and the piping system vulnerability. Ground shaking effect of an earthquake can be controlled by vibration isolators in fixed pumps, which were not installed in all visited WWPSs in the three case studies. Submersible pumps tolerate earthquake effects better than fixed pumps and submersible pumps are less vulnerable to earthquakes (Heubach, 2002; Rentoul, 2008). Check and control valves, particularly heavy ones should be fixed properly to the basement of the underground structures in WWPSs. Steel strips and proper stands should be applied to fix valves and pipes in pumping stations. According to site visiting of more than 45 wastewater pumping stations in New Zealand apart from two main pumping stations, had no proper fixing strips the mechanical parts. Almost all WWPSs built after 1995 are wet-well WWPSs. Therefore they do not have structural vulnerability and non structural components are expected to withstand earthquakes. According to the earthquake effects in wastewater systems in previous earthquake scenarios, recently constructed WWPSs should stand well during an earthquake, even those built as dry-well WWPS.

Joints and fitting are usually the most vulnerable parts of the WWPSs' piping system which can even be affected by a moderate earthquake. For instance, the only problem reported in the WWPSs after the 2007 Gisborne earthquake was joint leakages in a few WWPSs (Rentoul, 2009). Joints should tolerate shaking and displacement caused by earthquakes. In earthquake prone areas usually flexible joints should be installed to connect fittings and valves and pumps to pipes in order to tolerate shaking and displacement caused by earthquakes. Observations of WWPSs and some potable water pumping stations in the three earthquake prone cities in New Zealand have revealed fixed joints as the most predominant type. Only in 2 main WWPSs flexible joints were used to cope with longitudinal pipe movement. This type of joint facilitates installation and maintenance. 
Existence of deteriorated and fragile pipes in the under-ground structures of WWPSs is another source of vulnerability, which weakens in strength during earthquakes. Flowmeters have been installed in some WWPSs to monitor wastewater flow. Consequently, the old piping system has been renewed with new ones. The most popular pipe type, especially in the WWPSs built before 1995 is the cast iron pipe which compared with new pipe types is much more brittle and sensitive to shaking.

\section{CONCLUSION}

Wastewater treatment plants in the populated cities in New Zealand by themselves are not vulnerable to earthquakes. Power outage after major earthquakes is the most significant vulnerability in the updated wastewater treatment plants. For instance, UV disinfection units require high demand of power, which will not be satisfied by an emergency power generator. On the other hand, the treatment plants' power generators are not able to supply power for a long recovery period. Power shortage directly impacts the whole treatment process and decreases the quality of treated wastewater. Earthquake vulnerability of the simple wastewater treatment plants is relevant to WWPS vulnerability, located beside the treatment unit (usually filtration unit).

WWPSs' earthquake vulnerability in New Zealand has direct correlation with the structural and non-structural vulnerabilities. Non structural earthquake vulnerability is one of the predominant hazards in major earthquakes, especially from mechanical parts (piping and joints), electronic and electrical boards in dry-well wastewater pumping stations. Earthquake vulnerability of WWPSs' buildings, particularly those were built before 1976 is also prominent. Similar to wastewater treatment plants, most of the WWPSs can also be severely affected by a power outage due to lack of power generators. Findings from this research show that New Zealand needs to assess the upgrade of wastewater systems with a focus on the key vulnerabilities of WWTPs and WWPSs.

\section{ACKNOWLEDGEMENT}

All participants who provide information and recommendation are gratefully acknowledged including Hutt City Council, Capacity Company, GNS and MWH. In this study Numerous individuals provide valuable data and recommendation and deserve to acknowledge, Yon Cheong (Capacity Company), John Zhao, Jim Cousins and Grant Dellow (GNS), Ross Corkin and Lani Faatagi (Hutt City council), Mark Nelson (Marlborough district council), John Rentoul and Dave Hemmington (Gisborne city council), Dave Brunsdon (National Engineering Lifelines) and Steve J. Hutchison (MWH).

\section{REFERENCES}

Bannatyne, A. (2004) Hutt City wastewater treatment plant. Upper Hutt City, MWH.

Beattie, G. J. and Thurston, S. J. (2006) Changes to the seismic design of houses in New Zealand. In: Proceedings of the New Zealand society for earthquake engineering conference - 2006 NZSEE, 10-12 March 2006, Napier, New Zealand. Available at: http://db.nzsee.org.nz/2006/ Paper05.pdf

Bendimerad, F., Johnson, L., Coburn, A., Rahnama, M. and Morrow, G. (2000) Event report, Kocaeli, Turkey earthquake. RMS reconnaissance team. Available at: http://www.rms.com/Publications/Turkey_Event.pdf

Bevin, J. (2000) Seismic microzoning of the ground shaking hazard from soil geotechnical properties, Gisborne, New Zealand. In: House, A. and Watson, P. (eds.), Fourth Australia New Zealand young geotechnical professionals conference 2000: Proceedings, Australia, Perth, WA: University of Western Australia, pp. 1-9.

Building Act (2004) Building Act 2004 No 72. Wellington, New Zealand, New Zealand Government. 
Butcher, G., Andrews, L. and Cleland, G. (1998) The Edgecumbe Earthquake, A review of the 2 March 987 Eastern Bay of Plenty Earthquake. Centre of Advanced Engineering University of Canterbury.

Capacity-Co. (2004) Wastewater assessment, Hutt City. Hutt City, Capacity Co. and Hutt City council: 137.

Capacity-Co. (2008) Wastewater assessment, Hutt City. Hutt City Capacity Company and Hutt City Council: 137.

Dellow, G. D., Read, S. A. L., Begg, J. G., Van Dissen, R. J. and Perrin, N. D. (1992) Distribution of geological materials in Lower Hutt and Porirua, New Zealand: a component of a ground shaking hazard assessment, Bulletin of New Zealand National Society for Earthquake Engineering, 25(4), pp. 332-344.

Edwards, C. (2005) Preparing for disasters, Public Works, 136(7), pp. 47-48.

EERI (2010) Learning from earthquakes. The $\mathrm{M}_{\mathrm{w}}$ 8.8 Chile earthquake of February 27, 2010. EERI Special Earthquake Report. Available at: http://www.eeri.org/site/images/eeri_ newsletter/2010_pdf/Chile10_insert.pdf

Robertson, E. J. and Smith, E. G. C. (2004) A seismic site response and ground-shaking hazard assessment for Blenheim, New Zealand. In: 2004 NZSEE Conference, NZSEE, New Zealand. Available at: http://db.nzsee.org.nz/2004/ Paper45.pdf

Erdik, M. (1999) Report on 1999 Kocaeli and Duzce (Turkey) earthquakes. Istanbul, Bogazizi University. Available at: http://www.koeri.boun. edu.tr/depremmuh/eqspecials/kocaeli/Kocaelireport.pdf

François-Holden, C., Bannister, S., Beavan, J., Cousins, J., Field, B., McCaffrey, R., McVerry, G., Reyners, M., Ristau, J., Samsonov, S. and Wallace, L. (2008) The $\mathrm{M}_{\mathrm{w}} 6.6$ Gisborne earthquake of 2007: preliminary records and general source characterisation, Bulletin of the New Zealand Society for Earthquake Engineering, 41(4), pp. 266-277. Available at: http://www. iprpi.rpi.edu/IPRPI\%20publications/mccaffrey_ gizborne_2008.pdf

Gisborne District Council (2009) City wastewater treatment plant. [Online] Gisborne District Council. Available at: http://www.gdc.govt.nz/ city-wastewater-treatment-plant/
Gisborne District Council (2008) Wastewater pumping stations asset table. Gisborne District Council, Gisborne.

Heubach, W. F. (2002) Seismic screening checklists for water and wastewater facilities. American Society of Civil Engineers, Technical Council on Lifeline Earthquake Engineering, Monograph No. 22.

Lund, L., McLaughlin, J., Edwards, C., Laverty, G., Cornell, H., Guerro, A. R., Cassaro, M., Godshack, A., Brodt, G., Ballantyne, D. B., Eguchi, R., Pickett, M., Abu-Yasein, O., Lay, C., Schiff, A. J., Blacklock, J. R. and French, S. (1998) Water and wastewater systems. In: Schiff, A. J. (ed.), The Loma Prieta, California, Earthquake of October 17, 1989-Lifelines. U.S. Geological Survey Professional Paper 1552-A prepared in cooperation with the National Science Foundation, pp. 47-62. Available at: http://pubs.usgs. gov/pp/pp1552/pp1552a/pp1552a.pdf

Moehle, J. P. (1995) Northridge Earthquake of January 17, 1994 Reconnaissance Report, Volume 1, Earthquake Spectra, 11, Supplement C (April 1995) - Northridge Report Vol. 1.

Morkoc, E., Tarzan, L., Okay, O., Tufekci, H., Tufekci, V., Tolun, L. and Karakoc, F. (2007) Changes of oceanographic characteristics and the state of pollution in the Izmit bay following the earthquake of 1999, Environmental Geology, 53(1), pp. 103-112. doi:10.1007/s00254-006-0622-5

MWH (2005) HCC network by liquefaction potential (Jul05). Hutt City, MWH.

Napier City Council (2008) History of Napier wastewater treatment plant. [Online] Napier City Council. Available at: http://www.napier. govt.nz/index.php?cid=council/sewer/sew_ history\& mid $=15$

NCEER (1995) The Hanshin-Awiji earthquake of January 17, 1995: performance of lifelines. In: Shinozuka, M. (ed.) Technical report NCEER95-0015, November 3, 1995. Buffalo, N.Y. National Centre for Earthquake Engineering Research.

NZSEE (2006) Assessment and improvement of the structural performance of buildings in earthquake. NZSEE, New Zealand Society for earthquake engineering.

Read, G. F. (2004) Sewers: replacement and new construction. Oxford: Elsevier ButterworthHeinemann. 
Read, S. A. L. and Sritharan, S. (1993) Reconnaissance report on the Ormond earthquake - 10 August 1993, Bulletin of the New Zealand National Society for Earthquake Engineering, 26(3), pp. 292-308.

Rentoul, J. (2008) Gisborne wastewater system vulnerability to earthquakes. Gisborne city council, Personal communication.

Rentoul, J. (2009) Earthquake effects on the Gisborne wastewater system. Gisborne.

Schiff, A. J. (1995) Northridge earthquake: lifeline performance and post-earthquake response. Technical Council on Lifeline Earthquake Engineering (TCLEE) Monograph No. 8, New York: ASCE. 340 p.

Schiff, A. J. and Tang, A. K. (2000) Chi-Chi, Taiwan, earthquake of September 21, 1999: lifeline performance. Technical Council on Lifeline Earthquake Engineering (TCLEE) Monograph No. 18, Reston, VA: ASCE. 222 p.

Standards New Zealand (2004) Structural design actions. Part 5: Earthquake actions - New Zealand, NZS 1170.5:2004. Wellington, New Zealand, Standards New Zealand.
Tang, A., Cooper, T., Dueñas-Osorio, L., Eidinger, J., Fullerton, B., Imbsen, R., Kempner, L., Kwasinski, A., Pyrch, A., Schiff, A. and Wang, Y. (2010) Preliminary report 27 February $2010 \mathrm{M}_{\mathrm{W}} 8.8$ offshore Maule, Chile earthquake, Technical Council on lifeline earthquake engineering (TCLEE). Available at: http:// www.asce.org/uploadedFiles/Institutes/Technical_Activities_Committees_(TAC)/TCLEE\%20 Chile\%20Web\%20Report\%207.10.pdf

Van Dissen, R. J., Taber, J. J., Stephenson, W. R., Sritheran, S., Read, S. A. L., Mcverry, G. H., Dellow, G. D. and Barker, P. R. (1992) Earthquake ground shaking hazard assessment for the Lower Hutt and Porirua areas, New Zealand, Bulletin of New Zealand National Society for Earthquake Engineering, 25(4), pp. 286-302.

Vesilind, P. A., ed. (2003) Wastewater treatment plant design. Water Environment Federation, IWA Publishing.

Webb, T. H., Wesnousky, S. G. and Helmberger, D. V. (1985) A body-wave analysis of the 1966 Gisborne, New Zealand, earthquake, Tectonophysics, 113(3-4), pp. 271-282. doi:10.1016/0040-1951(85)90200-8

\section{SANTRAUKA}

\section{NUOTEKŲ VALYMO IR PUMPAVIMO STOČIŲ PAŽEIDŽIAMUMAS PER ŽEMĖS DREBĖJIMUS}

\section{Mohammad Reza ZARE, Suzanne WILKINSON, Regan POTANGAROA}

Naujojoje Zelandijoje žemès drebëjimai yra labiausiai tikètina stichinè nelaimè, apgyvendintose teritorijose galinti paveikti gyvybiškai svarbius tinklus. Šiame tyrime nagrinejjamas žemės drebejjimu poveikis nuoteku tinkluose veikiančioms valymo ir pumpavimo stotims, kurios yra gyvybiškai svarbios. Siekiant įvertinti, kaip žemès drebëjimai gali pažeisti nuoteku valymo stotis, buvo pasirinktos valymo stotys iš keturiu seismiškai aktyvių Naujosios Zelandijos zonų. Rezultatai parodè, kad Naujojoje Zelandijoje labiausiai pažeidžiamos paprastos atnaujintos nuoteku valymo stotys. Ivertintas ir trijuose seismiškai aktyviuose Naujosios Zelandijos miestuose esančių 45 nuoteku pumpavimo stočių pažeidžiamumas per žemės drebẻjimus. İvertinus nustatyta, kad nuoteku pumpavimo stotyse labiausiai pažeidžiami yra nestruktūriniai elementai. Kadangi kai kuriose nuoteku pumpavimo stotyse struktūru pažeidžiamumas yra didelis, reikia nedelsiant sudaryti rekonstrukcijos planą. 